\title{
Lazer Mikrodiseksiyon Tekniği İle Yaralanan Periferik Duyusal Nöronlar Üzerinde Nörotrofin-3 ve Nörotrofin-4/5'in Rejeneratif Etkilerinin Değerlendirilmesi
}

\author{
Evaluation of Regenerative Effects of Neurotrophin-3 and Neurotrophin-4/5 on \\ Peripheral Sensory Neurons Injured with Laser Microdissection Technique
}

\section{Ramazan Üstün ${ }^{1,2}$, Elif Kaval Oğuz ${ }^{2}$}

${ }^{1}$ Van Yüzüncü Yll Üniversitesi, Tip Fakültesi, Fizyoloji Anabilim Dal, Van

${ }^{2}$ Van Yüzüncü Yıl Üniversitesi, Tip Fakültesi, Sinirbilim Araştırma Birimi, Van

\section{Yazışma Adresi / Correspondence:}

Ramazan Üstün

Van Yüzüncü Yıl Üniversitesi, Tip Fakültesi, Fizyoloji Anabilim Dalı, Zeve Kampüsü, VAN

T: +90 5079309299 E-mail: ramazanustun@yyu.edu.tr

Geliş Tarihi / Received : 04.12.2018 Kabul Tarihi / Accepted : 29.01.2019

$\ddot{O} z$

Amaç Nörotrofin ailesinin önemli üyelerinden Nörotrofin-3 (NT3) ve Nörotrofin-4/5'in (NT4/5), mikroskop kontrollü lazer mikrodiseksiyon tekniğiyle, akson kesisi (aksotomi) oluşturulmuş dorsal kök gangliyon (DRG) nöronlarının hayatta kalma yeteneğini etkileyip etkilemediğini araştırmak. ( Sakarya Tip Dergisi 2019, 9(1):84-91 )

Gereçve Balb/C ırkı yetişkin farelerden anestezi altında ve aseptik koşullarda DRG çıkartıldı, DRG’lerden de nöron kültürü hazırlandı. Hücre ekiminden 48 saat sonra kültürler,

Yöntem NT3 $(50 \mathrm{ng} / \mathrm{ml}), \mathrm{NT} 4 / 5(50 \mathrm{ng} / \mathrm{ml})$ ve NT3+NT4/5 kombinasyonu ile muamele edildi. Nöritler gövdeden $200 \mu$ m uzaklıkta lazer ışını ile aksotomi edildi. Nöronların ölücanlı ayrımı için propidyum iyodür (PI) alım testi uygulandı. Nöronlar zaman aralıklı floresan mikroskobik görüntüleme sistemi ile görüntülendi.

Bulgular PI, ölü hücrelerin çekirdeğini floresan mikroskobu altında parlak kırmızı gösterdi. Tüm deney grupları, kontrol grubuna göre 24.ve 48. saatlerde hasarlı nöronların hayatta kalma oranlarında önemli artış gerçekleștirdi $(\mathrm{p}<0,001)$. En fazla hayatta kalma oranı NT3+NT4 grubunda, sonra sırasıyla NT3, NT4 ve kontrol gruplarında görüldü $(\mathrm{p}<0,001)$. Hayatta kalma oranları 48. saatte 24. saate göre azalma gösterse de bu azalma istatistiksel olarak önemsizdi.

Sonuç NT3+NT4/5 kombinasyonu, NT3 (50 ng/ml) ve NT4/5 (50 ng/ml), in vitro aksotomi hasarı modelinde yaralı DRG nöronlarının hayatta kalma oranlarını artırmaktadır. Sunulan veriler, nörotrofik faktörlerin periferik sinirlerin mekanik yaralanmalarında terapötik potansiyele sahip olduğunu göstermektedir.

Anahtar Dorsal kök gangliyon; duyusal nöron; aksotomi; Nörotrofin-3; Nörotrofin-4/5

kelimeler

Abstract

Objective To investigate whether of Neurotrophin-3 (NT3) and Neurotrophin-4/5 (NT4/5), important members of the neurotrophin family, affect the survival ability of dorsal root ganglion (DRG) neurons that had axonal injury induced by axotomy with a microscope-controlled laser microdissection technique. (Sakarya Med J 2019, 9(1):84-91)

Materials and DRGs were harvested from Balb/C adult mice under anesthesia and aseptic conditions. DRG neuron culture was prepared. After culturing the DRG neurons for forty-eight hours, the cultures

Methods were treated with NT3 $(50 \mathrm{ng} / \mathrm{ml}), N T 4 / 5(50 \mathrm{ng} / \mathrm{ml})$ and NT3+NT4/5 combination. Neurites were axotomized at $200 \mu \mathrm{m}$ distance from the perikaryon with the microscope-controlled laser beam. A propidium iodide (PI) uptake test was performed to determine the dead-alive distinction of neurons. Neurons were visualized with a time-lapse fluorescent microscopic imaging system.

Results PI shows the dead cells' nucleus as bright red under the fluorescence microscope. All experimental groups showed a significant increase in axotomized-neurons' survival rates at 24th and 48th hours compored to control group $(p<0,001)$. It was determined that the highest survival rate was in NT3 $+N T 4$ group, then NT3, NT4 and control groups respectively $(p<0,001)$. Although the survival rates decreased at the 48 th hour, compared to that at 24th hour, this decrease was statistically insignificant though.

Conclusion Combination of NT3+NT4/5, NT3 $(50 \mathrm{ng} / \mathrm{ml})$ and $N T 4 / 5(50 \mathrm{ng} / \mathrm{ml})$ increased the survival rate of DRG neurons in vitro axotomy injury model. The data presented suggested that neurotrophic factors appears to have therapeutic potential in the mechanical injury of peripheral nerves.

Key words Dorsal root ganglion; sensory neuron; axotomy; Neurotrophin-3; Neurotrophin-4/5 


\section{GIIRIŞ}

Periferik sinir sisteminde kümelenen nöron toplulukları gangliyon olarak adlandırılır. Gangliyonlar, etrafları sıkı bağ dokuyla sarılı nöron ve glia hücrelerinden oluşan yuvarlak yapılardır. ${ }^{1}$ Duyu ve otonom gangliyon olarak iki grupta sınıflandırılırlar. Duyu gangliyonu grubunda yer alan dorsal kök gangliyonlar (DRGs) komşu iki vertabra arkı arasında yerleşiktir. Bu gangliyonlarda yer alan nöronların temel görevi farklı duyu reseptörlerince üretilen sinyalleri merkezi sinir sistemine iletmektir. ${ }^{2}$

Periferik sinir yaralanmaları sıklıkla zayıflatıcı motor ve duyusal bozukluklara neden olur. Cerrahi teknik ve rekonstrüktif seçeneklerde önemli gelişmelere rağmen, sonuçlar genellikle zayıftır. Günümüzde periferik sinir hasarının tedavisi ne yazık ki yoktur. ${ }^{3}$

Nörotrofik faktörler, nöronal gelişim, nöronların hayatta kalması, proliferasyon, farklılaşma, myelinizasyon, aksonal büyüme ve sinaptik plastisite gibi pek çok süreçte görev alırlar. Nörotrofik faktörlerin rejenerasyona da katkıda bulundukları bilinmektedir., ${ }^{4,5}$ Nörotrofin ailesinin en iyi bilinen üyeleri; sinir büyüme faktörü (NGF), beyin kökenli büyüme faktörü (BDNF), nörotrofin-3 (NT3) ve nörotrofin-4/5 (NT4/5)'tir. Bunlara ilaveten sitokin ailesi olarak bilinen lösemi inhibe edici faktör (LIF), sillier nörotrofik faktör (CNTF), glial hücre kökenli faktör (GDNF) ve fibroblast büyüme faktörü (FGF) de primer duyu nöronlarının gelişimine ve yaşamlarının devamına katkıda bulunan diğer moleküllerdir. ${ }^{6}$

Genellikle iskelet kasında sentezlenen nörotrofin ailesinin bir üyesi olan NT3'ün aynı zamanda motor nöronların gelişimine de katkısı olduğu da bilinmektedir. NT3’ün veya onun reseptörü olan Tropomyosin receptor kinase C’nin (TrkC) ekspresyonunda meydana gelen kusurlar şiddetli duyu hasarlarına neden olurlar. NT3 geni olmayan farelerde ileri derecede hareket kusurları meydana gelirken; bu hayvanların duyu ve sempatik nöronlarında önemli miktarda kayıpların olduğu gözlenir.7 NT3’ün aynı zamanda embriyonik DRG nöronlarının canlılığının korunmasında da teşvik edici etkiye sahip olduğu bildirilmiştir. ${ }^{8}$ NT4 memeli nörotrofini iki grup tarafından klonlandığından dolayı NT-4 veya NT-5 olarak adlandırılmış, ancak daha yaygın NT 4/5 olarak anılmaktadır. ${ }^{9}$

Bu çalışmada; fare DRG nöron kültürlerinde, mikroskop kontrollü lazer mikrodiseksiyon tekniği kullanılarak, aksonal uzantıları hassas lazer ışını ile kesilen nöronların hayatta kalma kabiliyetini, NT3 ve NT4/5'in etkileyip etkilemediğinin araştırılması amaçlandı.

\section{GEREÇ VE YÖNTEMLER}

\section{Deney hayvanları}

Çalışmada, Van Yüzüncü Yıl Üniversitesi Deney Hayvanları Araştırma Ve Uygulama Merkezi’nden sağlanan 6-8 haftalık Balb-C irkı fareler kullanıldı. Deney hayvanlarının bakımı, beslenmesi ve kullanımına ilişkin tüm prosedürler, Avrupa Birliği Konseyinin Hayvan Deneyleri Direktifi 86/609/ECC uyarınca, Hayvan Deneyleri Yerel Etik Kurulu tarafindan onayland. Fareler intaperitoneal ketamin uygulamasıyla $(40 \mathrm{mg} / \mathrm{kg})$ anestezi edildi, servikal transeksiyonla öldürüldü. DRG’ler aseptik koşullarda, stereo mikroskop altında çıkarıldı. Gangliyonlar, hücre kültürü yapılıncaya kadar soğuk RPMI 1640 vasatında bekletildi. ${ }^{10,11}$

\section{Hücre kültürünün hazırlanması}

Enzimatik parçalamaya kolajenaz ile başlandı, HBSS ile yıkandı, tripsin ile enzimatik ayrıştırma gerçekleştirildi. Mekanik ayrıştırma gangliyonların tiriturasyonuyla yapildı. Medyuma DNAz eklendi, $50 \mathrm{~Hz}$ frekansta ajitasyon işlemi yapıldı. Santrifüj ile ayrışan hücreler çöktürüldü, pellet NBA, FCS ve tripsin inhibitörü ile muamele edildi, percoll gradienti ile nöronlar diğer hücrelerden ve doku kalıntılarından ayrıldı. Elde edilen nöronlar, NBA içinde $600 \mu \mathrm{l}$ süspansiyon olarak bir gün öncesinde Poly-L-Lysine ve laminin ile kaplanan petri kaplarına ekildi. hücreler tabana tutunduktan sonra medyum NBA ile $1,5 \mathrm{ml}$ hacme tamamland1, nöron kültürleri \%5 CO2 ayarlı 37 0C sıcaklık, \%100 nem sağlanan etüvde, 48 saat inkübasyona bıra- 
$\mathrm{k}_{1 \mathrm{ld}} 1^{10,11}$

\section{Nöronlarda canlılıkların doğrulanması}

Hücre Kültürü medyumuna propidyum iyodür $(7.5 \mu \mathrm{M})$ eklendi. Propidyum iyodür alım testi ile çekirdeği boyanan, floresan mikroskopta parlak kırmızı renk veren hücreler ölü, boyanmayan hücreler canlı kabul edildi (șekil 1).

\section{Aksotomi (akson kesisi) modelinin olușturulması}

Aksotomi için canlı nöronlar seçildi. Ayrıca canlı nöronların membranlarının deforme olmamasına, kabarcık, vakuol veya boncuklu nevritler gibi stres belirtileri göstermemesine özen gösterildi (Şekil 2a). Aksotomi için nöritlerin boyunun en az $200 \mu \mathrm{m}$, en kalın, en uzun nöritler olmalarına dikkat edildi (Şekil 2a). Aranan özellikler zaman aralıklı mikroskop sisteminde (Cell Observer-Zeiss) seçildi (Şekil 2a). Aksotomi işlemi, ultraviyole (UV) laser ünite ataçmanl, özel invert mikroskop sistemi ile gerçekleştirildi (Şekil 2b). Bu sistem PALM Microlaser Technolojisi ve LPMC sisteminden oluşmaktadır, sistemde laser üretici ünite, motorize invert mikroskop (Axiovert 200M) ve kontrolleri sağlayan özel yazılımlı (RoboLPC) bilgisayar bulunmaktadır. Mikroskopta bulunan laser ünitesi 337 nm dalga boyunda, her biri 3 ns süren ve yaklaşık olarak $300 \mu \mathrm{J}$ enerji salan darbeler üretmektedir. Laser mikrodiseksiyon sistemiyle aksotomi yapmak için 63X kuru faz kontrast objektif (Achroplan N.A. 0.75, Zeiss Almanya), laser ışını, mikroskobu ve mikroskoba bağlı olan CCD kamerayı kontrol eden bilgisayar sistemi kullanıldı. ${ }^{11,12}$ (Şekil 2b)

\section{Aksotomi yapılan nöronlara tedavi amaçlı nörotrofinlerin uygulanması}

Yaralı nöronları tedavi etmek için deney gruplarına sırasıyla; NT3 (50 ng/ml), NT4/5 (50 ng/ml) ve NT3 (50 ng/ $\mathrm{ml})+\mathrm{NT} 4 / 5(50 \mathrm{ng} / \mathrm{ml})$ kombinasyonu eklendi, kontrol grubuna hiç birşey eklenmedi. Seçilen nöronların aksonları gövdeden $200 \mu \mathrm{m}$ uzaklıktan kesildi (Şekil 2b).

\section{Hücre takip ve görüntüleme}

Aksotomi sonrası kültürler, canlı hücre (Cell Observer-Zeiss) görüntüleme (zaman aralıklı mikroskopi) sistemine transfer edildi. Görüntüleme 20X büyütmeli objektifle yapıldı. Sistem motorize bir invert mikroskop (Axiovert 200M) ile tüm fonksiyonların kontrol edilip programlanabildiği bilgisayar ve yazılımından oluşmaktadır. Mik-
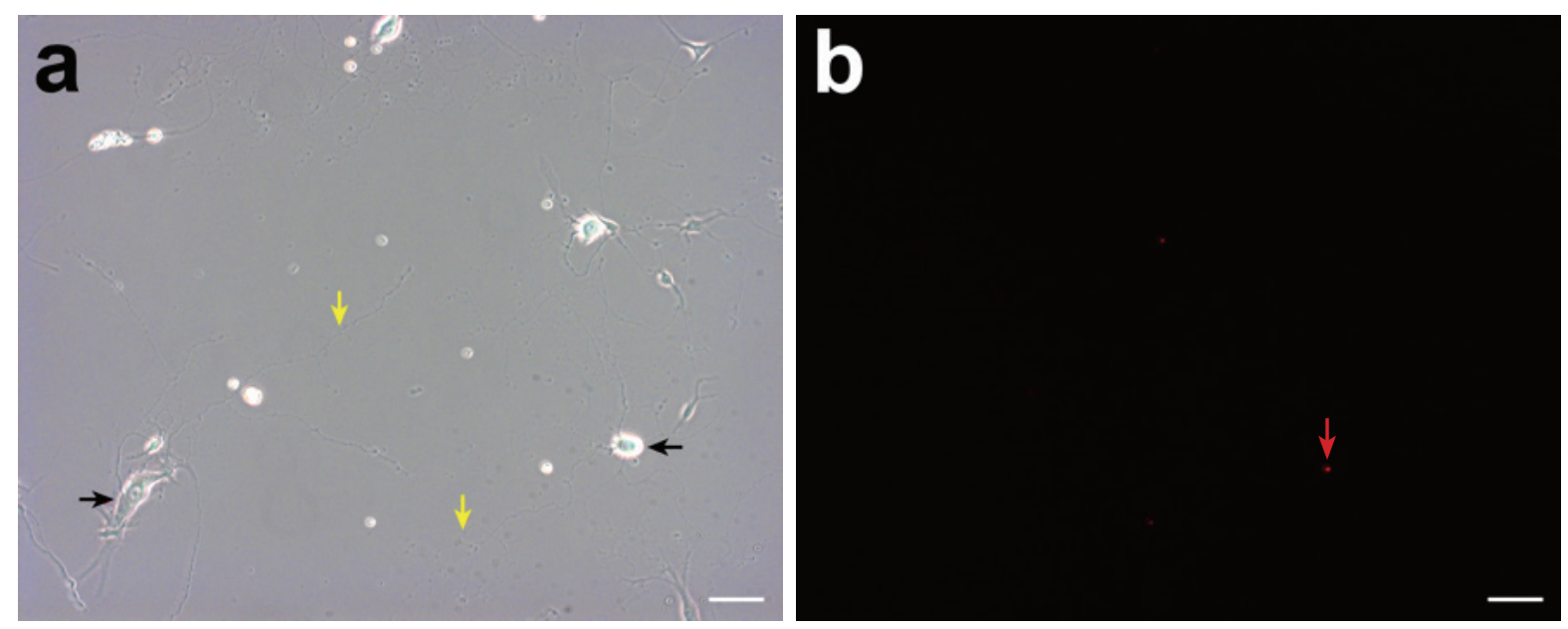

Şekil 1. Aksotomi öncesinde nöronların ölü-canlı olduklarının tespiti. (a) Hücrelerin faz-kontrast mikroskop görüntüsü. Siyah oklar canlı DRG nöronlarını gösteriyor, sarı oklar nöron gövdesinden $200 \mu \mathrm{m}$ uzaklıkta nörit mesafesini gösteriyor. (b) Kırmızı floresan mikroskobik görüntü. Kırmızı floresan görüntü a resminde siyah okla gösterilen nöronların ölü olmadıklarını doğruluyor. Kırmızı ok, ölü satellit hücresini gösteriyor. Skala bar: $50 \mu \mathrm{m}$ 

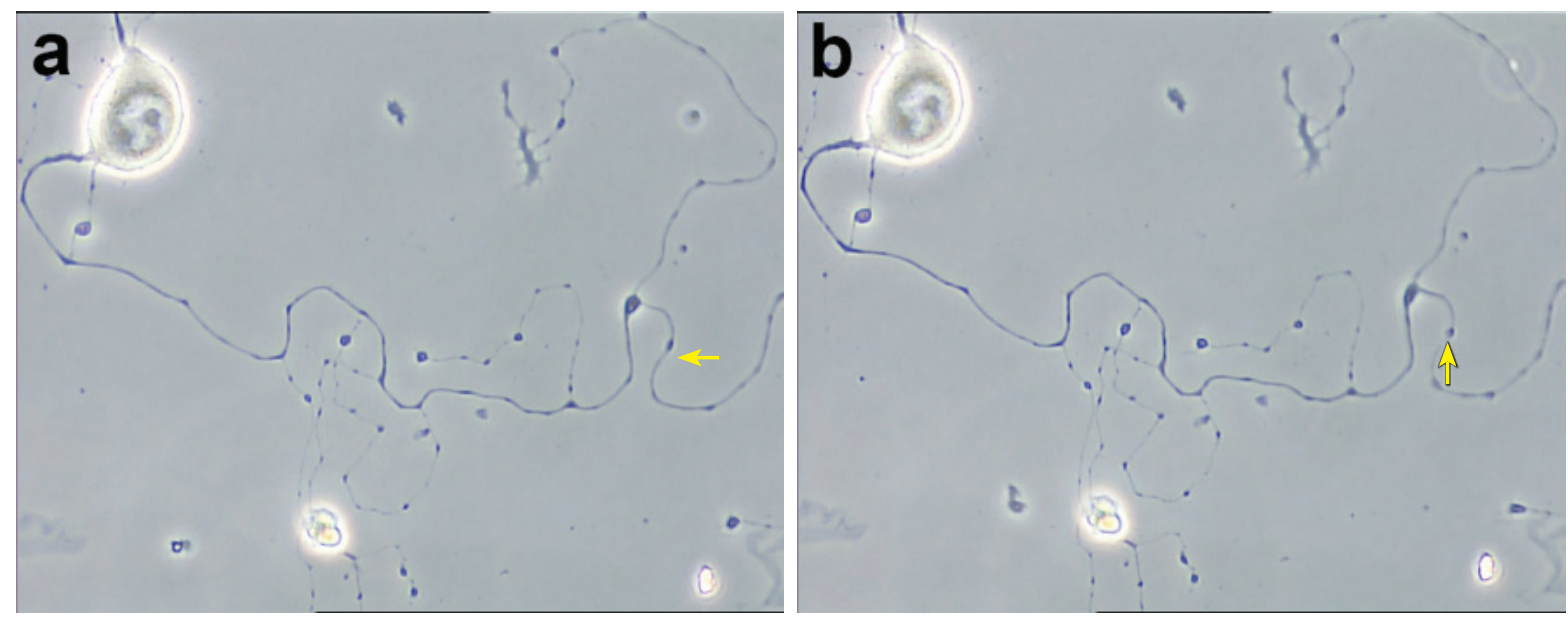

Şekil 2. Laser mikrodiseksiyon sisteminde DRG nöronunun 63X büyütmeli objektifde görüntüsü. (a) aksotomi öncesi görüntü, sarı ok aksotomi yapılacak alanı gösteriyor. (b) aksotomi sonrası görüntü, sarı ok aksotomi yapılan alanı gösteriyor.

roskop üzerinde bulunan dijital kamerayla görüntüler bilgisayar ortamına aktarılabilmektedir. Tabla üzerinde bulunan ve preparatın yerleştirildiği inkübasyon kutusu destek üniteler sayesinde hücreler için fizyolojik koşullar sağlanmaktadır (37 ${ }^{\circ} \mathrm{C}, \% 5 \mathrm{CO} 2$, nem). Sistemde kullanılan bilgisayar programı (Axiovision 3.1) mikroskobun tüm fonksiyonlarının bilgisayar ortamında düzenlenebilmesine olanak sağlamaktadır. Görüntülenen pozisyonlar özel bir formatla (zvi) depolanır ve bu görüntüler birleştirilerek film haline getirilebilir (24). Çalışmada görüntülemeler sırasıyla aksotomi öncesi (Şekil 3a), aksotomiden 24 saat (Şekil 3b) ve 48 saat (Şekil 3c) sonra gerçekleştirildi. Aksotomi uygulanmış hasarlı nöronların hayatta kalma oranları \% olarak hesapland. ${ }^{13}$ (Şekil.4)

\section{İstatistiksel Analiz}

İstatistik hesaplamalar ve analizler için SPSS MINITAB paket programı kullanılmıştır. Görüntü analizleri 24. ve 48. saatlerde gerçekleştirildi. Gruplar arası farkın belirlenmesi amacıyla oran karşılaştırılması Z testi ile yapıldı. Çalışmada elde edilen sonuçlar tanımlayıcı istatistik olarak ortalama \pm standart sapma kullanılarak özetlendi ve istatistiksel anlamlılık düzeyi $\mathrm{p}<0.05$ olarak alındı.

\section{BULGULAR}

Aksonal yaralanma modeli oluşturmak için seçilen DRG nöronlarının, aksotomi öncesinde (inkübasyondan 48 saat sonra) canlı oldukları ve nöritlerini uzattıkları doğrulandı (Şekil 1). DRG nöronlarının aksonal yaralanma modeli, lazer mikro diseksiyon tekniğiyle başariyla oluşturuldu (Şekil 2). Kontrol (aksotomi), NT3 (50 ng/mL), NT4/5 (50 $\mathrm{ng} / \mathrm{mL}$ ) ve NT3+NT4/5 gruplarında hücrelerde ölüm-canlılık oranları, zamana (aksotomi ve tedavi uygulamasının 24. ve 48. saatlerinde) bağlı olarak incelendi (Şekil 3). Yaralı nöronların hayatta kalma oranları tedaviden 24 saat sonra; Kontrol grubunda \%36.73 (18/49), NT3 deney grubunda $\% 80.39$ (41/51), NT4/5 deney grubunda \%74.00 (37/50), NT3+NT4/5 deney grubunda \%94.44 (51/54) belirlendi. Tedaviden 48 saat sonra; Kontrol grubunda \%28.57 (14/49), NT3 deney grubunda \%76.47 (39/51), NT4/5 deney grubunda \%64.00 (32/50), NT3+NT4/5 kombinasyonu deney grubunda \%88.88 (48/54) saptandı (Şekil 4). Hem 24. saatte hem de 48. saatte deney grupları (NT3, NT4/5, NT3+NT4/5) kontrol grubu ile karşılaştırıldığında nöronların hayatta kalma oranlarında istatistiksel olarak önemli artış sağlandı $(\mathrm{p}<0,001)$ (Şekil 4). Deney grupları arasında yapılan karşılaştırmada NT3+NT4/5 kombinasyon grubunun, NT4/5 grubundan olan farkı hem 24.saatte ( $\mathrm{Z}=2,94 ; \mathrm{P}=0,003)$ hem de 48.saatte önemliydi. ( $\mathrm{Z}=$ 


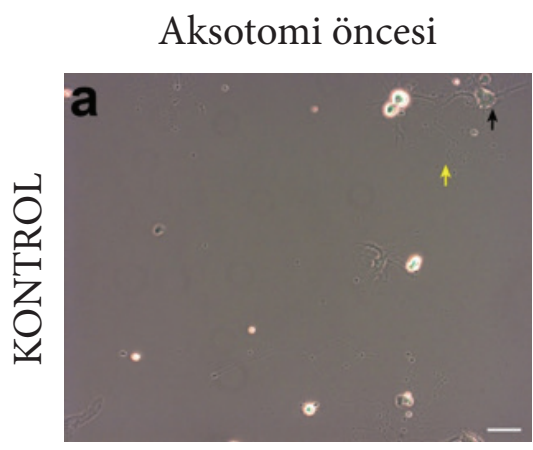

Aksotomi sonrası 24. saat

Aksotomi sonras1 48. saat
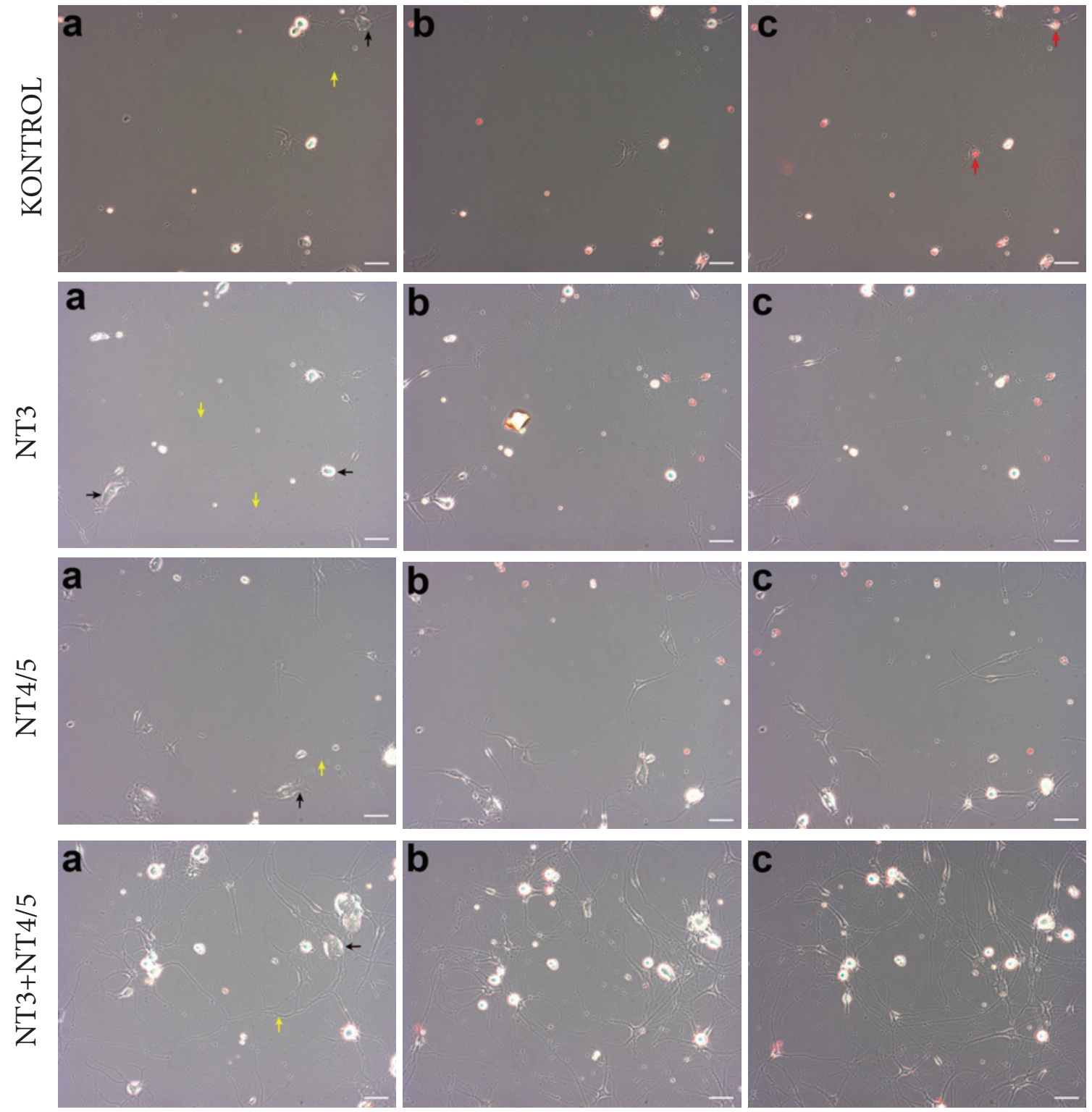

Şekil 3: Yaralı nöronların tedaviye verdikleri yanıtlar. (a) Aksotomi öncesi faz-kontrast+kırmızı floresan (birleştirilmiş) görüntüler. (b) Aksotomi sonrası 24. saat birleştirilmiş görüntüler. (c) Aksotomi sonrası 48. saat birleştirilmiş görüntüler. Siyah oklar canlı nöronları, sarı oklar aksotomi yapılacak noktaları, kırmızı oklar ölen nöronları gösteriyor. Skala bar: $50 \mu \mathrm{m}$.

$-3,10 ; \mathrm{P}=0,002)$. Yine NT3+NT4/5 kombinasyon grubunun, NT3 grubundan olan farkı 24.saatte önemliydi $(Z=$ 2,20 $\mathrm{P}=0,027)$, fakat 48. saatdeki farkı önemli değildi ( $\mathrm{Z}$ $=1,70 \mathrm{P}=0,090)$. NT3 ile NT4/5 grupları arasında her iki zaman diliminde de istatistiksel fark yoktu. Hayatta kalma oranları 48. Saatte, 24. saate göre azalma gösterse de bu azalma istatistiksel olarak önemsizdi. 


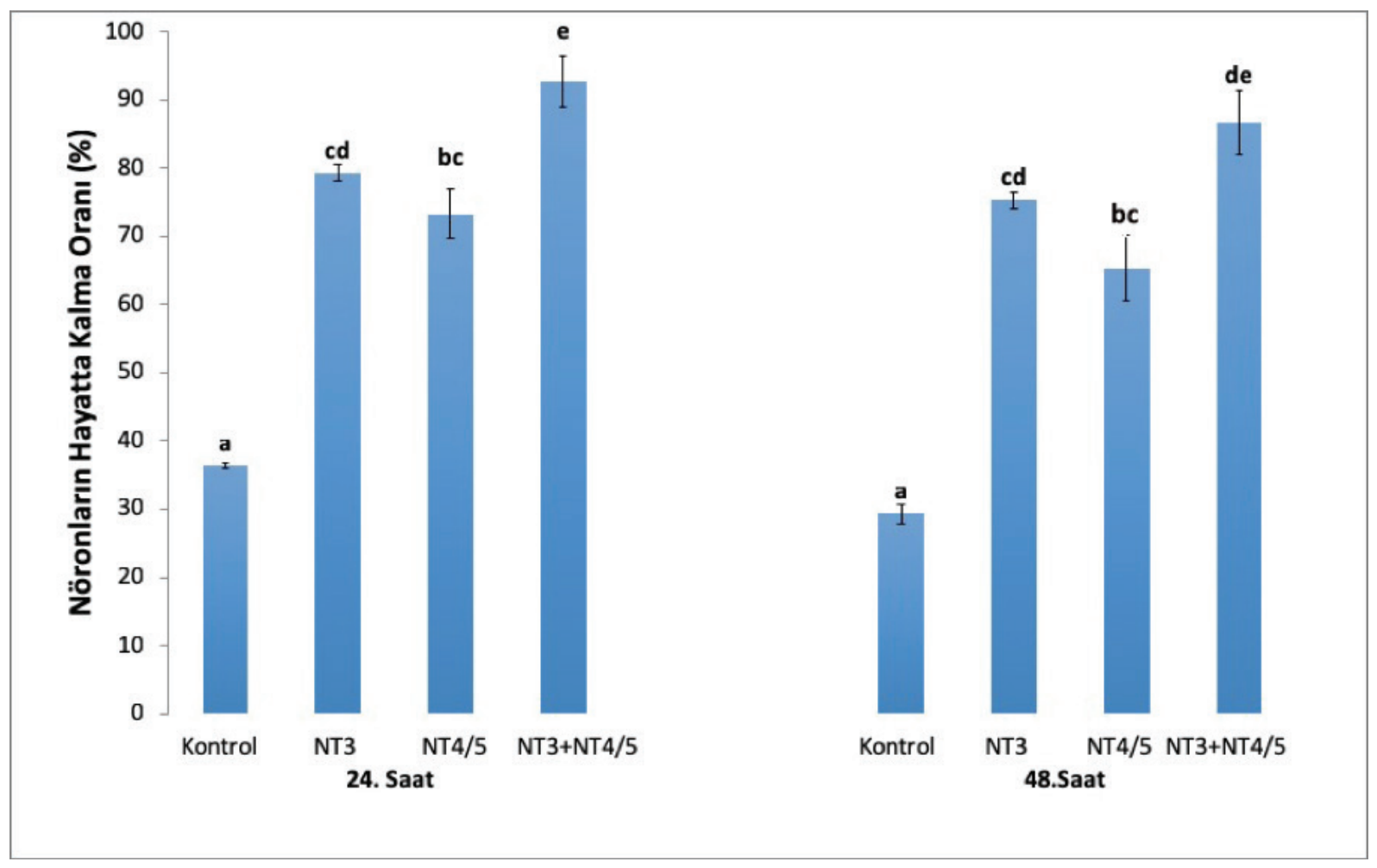

Şekil 4. Aksotomi hasarlı nöronların hayatta kalma oranları. Aksonal yaralanmadan ve tedavi uygulamasından 24 saat ve 48 saat sonra hasarlı nöronların hayatta kalma oranları. Farklı harfler istatistiksel farklılığı göstermektedir $(\mathrm{P}<0.05)$.

\section{TARTIŞMA}

Hücre Kültürü; Araştırılan konuya ilişkin daha sınırlı bilgi ve veri sunsa da hücre kültüründen alınan sonuçlar diğer fizyolojik değişkenlerden uzak olduğundan in vivo çalışmalara kıyasla daha optimizedir. Bu avantajı dolayısıyla hücre kültürü çalışmaları in vivo ve faz çalışmalarına geçişte ilk basamak olarak kabul görmüştür. ${ }^{14,15}$

Günümüzde etkin olarak uygulanan çok çeşitli sinir hasar modelleri mevcuttur. Bunlardan en yaygın kullanılanılanları siyatik sinir, optik sinir, omurilik kesileri ve kortikal yaralama gibi in vivo hasar modelleridir. ${ }^{16,17}$ In vivo modeller her ne kadar nöronal hasara karşı cevapları açıklamaya yardımcı olsa da yeterli değildir. Halbuki sinir hasarlarına karşı moleküler ve hücresel tepkilerin ve mekanizmaların aydınlatılmasında in vitro metodlar daha etkin kullanılmaktadır. Kültür ortamlarında uygulanabilen birçok in vitro hasar modeli bulunmaktadır; bunlardan bazıları mikro bıçaklar, makaslar, bistüriler, cam kapillerler gibi malzemelerle mekanik hasar oluşturma modelleridir. ${ }^{18} \mathrm{Bu}$ çalışmada uygulanan mikrolazer ışını ile aksotomi hasar modeli; daha kolay, etkin, kontrol edilebilir ve kesin bir uygulama olmakla birlikte yeni ve özgün bir tekniktir. Sistematik olarak nörit kesiminde ilk kez Higgins ve arkadaşları tarafından kullanılan bu yöntem de UV lazer ile hedeflenen nöritlerin kesimi in vitro ortamda yapılmıştır. ${ }^{12,13}$ Bu çalışmada rutin olarak kullanılan bir yöntem olan laser mikrodiseksiyon mikroskobu ile hassas ve etkin bir şekilde aksotomi gerçekleştirilmiştir. ${ }^{11}$

Sinir sisteminin işlevini sağlıklı yürütebilmesi için merkezi ve periferik sinir sistemindeki nöronal bağlantıların özgün ve doğru bir şekilde kurulması gerekir. Sinir sisteminin bu görevlerini yerine getirmesinde etkili olan nörotrofik faktörler nöronların yaşam süresine, büyümesine, morfolojik değişikliklerine, nöronlar arası sinyal iletimine ve 
hayatta kalmasına etki ederler. ${ }^{19}$ Nörotrofik faktör ailesinin üyeleri olan NT3 ve NT4/5'in merkezi ve periferik sinir sistemi nöronlarının canlılıklarını sürdürmelerine ve rejenerasyonlarına katkıda bulunduğu bilinmektedir. ${ }^{20}$ NT3’ün kültürü yapılan dorsal kök gangliyon hücrelerinin \%60’ından fazlasında canlılığın korunmasını teşvik ettiği ve trigeminal mezensefalik nukleustaki proprioseptif nöronlar gibi normalde NGF’e duyarsız olan duyu nöronlarından bazılarını kurtardıkları saptanmıştır. ${ }^{21,22}$ Her ne kadar NT3'ün proprioseptif duyu nöronlarını seçici olarak kurtardığı bilinse de aynı zamanda yenidoğan farenin aksotomi hasarlı motor nöronlarının canlılığının devamında da destekleyici etkisinin olduğu bildirilmiştir. ${ }^{23}$ NT4/5'in ise dopaminerjik nöronların korunmasında aktif rol oynadığ́1 gösterilmiştir. ${ }^{24}$ Ayrıca, NT4/5'in oksidatif stresin oluşturduğu hasarı azalttığı ve bu etkiye karşı korunmada aktif rol oynadığı, trkB reseptörüne bağlandığı, spinal motor nöronların ve farklı populasyonlarda yer alan duyu nöronlarının hayatiyetini de arttırdığı bildirilmiştir. ${ }^{25}$

$\mathrm{Bu}$ çalışmada aksotomi hasarına maruz kalan yaralı DRG nöronlarının hayatta kalmalarına, NT3 ve NT4/5'in katkıda bulundukları ilk kez ortaya konmuştur. Nörotrofik faktörlerin etkileri, kendi aralarında karşılaştırıldığında NT3'ün koruyucu etkisi 24. ve 48. Saatlerde NT4/5'e göre daha yüksek eğilim gösterse de aralarında istatistiksel bir fark bulunamadı. Bununla birlikte NT3+NT4/5 kombinasyonunun 24. Saatte koruyucu etkisi, NT3 ve NT4/5'in bireysel tedavilerine göre önemli oranda yüksekti, 48.saatte ise NT4/5'e göre yüksekti. NT3'ün bireysel etkisini büyük bir afiniteyle Tirozin kinaz $C$ reseptörü üzerinden gerçekleştirdiği, daha az afiniteyle Tirozin kinaz A ve Tirozin kinaz B reseptörleri üzerinden de gerçekleştirdiği bildirilmiştir. ${ }^{26}$ Buna mukabil NT4/5'in etkisini Tirozin kinaz $B$ reseptörü üzerinden gerçekleştirdiği rapor edilmiştir. ${ }^{27}$ NT3+NT4/5 kombinasyonun daha yüksek nöronal sağ kalım sağlaması, bu yeteneğin iki farklı yolak üzerinden sağlanmış olabileceğini işaret etmektedir. Trk reseptörlerine bu nörotrofinlerin bağlanması, otofosforilasyona ve aşağı akım sinyal kaskadlarının aktivasyonuna yol açar. Bu yolaklar da nöronal sağkalımda, aksonal büyümede ve sinaptik plastisitede önemli rollere sahiptir. ${ }^{26}$

\section{SONUÇ}

Deney ve kontrol gruplarındaki yaralı DRG nöronları, hayatta kalma oranları bakımından aksotomi sonrası 24 . ve 48. saatlerde karşılaştırıldı. Deney (NT3, NT4/5 ve NT3+NT4/5 kombinasyon) gruplarının hayatta kalma oranlar1, kontrol grubundan hem 24. hem de 48.saatlerde daha yüksekti. Deney grupları kendi aralarında karşılaştırild1, NT3+NT4/5 kombinasyon grubunun hayatta kalma oranı NT4/5 grubundan hem 24. hem de 48.saatlerde daha yüksekti. NT3+NT4/5 kombinasyon grubunun hayatta kalma oranı NT3 grubundan sadece 24.saatte daha yüksekti. NT3'ün koruyucu etkisi NT4/5’e göre daha yüksek eğilim gösterse de aralarında istatistiksel bir fark yoktu. NT3 ve NT4/5 nörotrofik faktörlerinin aksotomi sonrasında yaralı nöronların hayatta kalmasını önemli oranda artırdıkları, bu nörotrofik faktörlerin kombinasyon tedavisinin sinerji oluşturdukları ilk kez bu çalışmada ortaya konuldu. Sunulan veriler, nörotrofik faktörlerin periferik sinirlerin mekanik yaralanmalarında terapötik potansiyele sahip olduğunu göstermektedir, daha ileri araştırmalara gereksinim vardır. 


\section{Sakarya Tip Dergisi 2019;9(1):84-91}

\section{Kaynaklar}

1. Kandel ER, Schwartz JH, Jessell TM, Siegelbaum S, Hudspeth AJ. Principles of neural science. 5th ed. New York, NY; London: McGraw-Hill; 2013. l, 1709 p. p.

2. de Luca AC, Faroni A, Reid AJ. Dorsal Root Ganglia Neurons and Differentiated Adipose-derived Stem Cells: An In Vitro Co-culture Model to Study Peripheral Nerve Regeneration. Journal of Visualized Experiments. 2015;96.10.3791/52543.

3. Tuffaha SH, Budihardjo JD, Sarhane KA, Khusheim M, Song D, Broyles JM, et al. Growth Hormone Therapy Accelerates Axonal Regeneration, Promotes Motor Reinnervation, and Reduces Muscle Atrophy following Peripheral Nerve Injury. Plast Reconstr Surg. 2016;137(6):1771-80.

4. Gordon T. The role of neurotrophic factors in nerve regeneration. Neurosurg Focus. 2009;26(2):E3.

5. Lu B, Pang PT, Woo NH. The yin and yang of neurotrophin action. Nat Rev Neurosci. 2005;6(8):603-14.

6. Xiao N, Le QT. Neurotrophic Factors and Their Potential Applications in Tissue Regeneration. Arch Immunol Ther Ex. 2016;64(2):89-99.

7. Ernfors P, Lee KF, Kucera J, Jaenisch R. Lack of neurotrophin-3 leads to deficiencies in the peripheral nervous system and loss of limb proprioceptive afferents. Cell. 1994;77(4):503-12.

8. Funakoshi H, Frisen J, Barbany G, Timmusk T, Zachrisson O, Verge VM, et al. Differential expression of mRNAs for neurotrophins and their receptors after axotomy of the sciatic nerve. J Cell Biol. 1993;123(2):455-65.

9. Berkemeier LR, Winslow JW, Kaplan DR, Nikolics K, Goeddel DV, Rosenthal A. Neurotrophin-5 - a Novel Neurotrophic Factor That Activates Trk and Trkb. Neuron. 1991;7(5):85766.

10. Üstün R, Oğuz EK. Degenerative effect of Ankaferd Blood Stopper on mice peripheral sensory neurons $\langle I>$ in vitro $</ I>$. Folia Neuropathologica. 2018;56(1):67-74.

11. Ustun R, Oguz EK, Seker A, Korkaya H. Thymoquinone protects DRG neurons from axotomy-induced cell death. Neurol Res. 2018:1-8.

12. Cengiz N, Ozturk G, Erdogan E, Him A, Oguz EK. Consequences of neurite transection in vitro. J Neurotrauma. 2012;29(15):2465-74.

13. Ozturk G, Cengiz N, Erdogan E, Him A, Oguz EK, Yenidunya E, et al. Two distinct types of dying back axonal degeneration in vitro. Neuropathol Appl Neurobiol. 2013;39(4):362-76.

14. Helmrich A, Barnes D. Animal cell culture equipment and techniques. Methods Cell Biol. 1998;57:3-17.

15. Merten OW. Introduction to animal cell culture technology-past, present and future. Cytotechnology. 2006;50(1-3):1-7.

16. Geuna S. The sciatic nerve injury model in pre-clinical research. Journal of Neuroscience Methods. 2015;243:39-46.

17. Tzekov R, Quezada A, Gautier M, Biggins D, Frances C, Mouzon B, et al. Repetitive mild traumatic brain injury causes optic nerve and retinal damage in a mouse model. J Neuropathol Exp Neurol. 2014;73(4):345-61.

18. Geuna S, Raimondo S, Fregnan F, Haastert-Talini K, Grothe C. In vitro models for peripheral nerve regeneration. Eur J Neurosci. 2016;43(3):287-96.

19. Huang EJ, Reichardt LF. Neurotrophins: roles in neuronal development and function. Annu Rev Neurosci. 2001;24:677-736.

20. Takeda M, Suzuki Y, Obara N, Tsunekawa H. Immunohistochemical detection of neurotrophin-3 and-4, and their receptors in mouse taste bud cells. Arch Histol Cytol. 2005;68(5):393403.

21. Maisonpierre PC, Belluscio L, Squinto S, Ip NY, Furth ME, Lindsay RM, et al. Neurotrop- hin-3: a neurotrophic factor related to NGF and BDNF. Science. 1990;247(4949 Pt 1):144651 .

22. Hohn A, Leibrock J, Bailey K, Barde YA. Identification and characterization of a novel member of the nerve growth factor/brain-derived neurotrophic factor family. Nature. 1990;344(6264):339-41.

23. Li L, Oppenheim RW, Lei M, Houenou LJ. Neurotrophic agents prevent motoneuron death following sciatic nerve section in the neonatal mouse. J Neurobiol. 1994;25(7):759-66.

24. Hyman C, Juhasz M, Jackson C, Wright P, Ip NY, Lindsay RM. Overlapping and Distinct Actions of the Neurotrophins Bdnf, Nt-3, and Nt-4/5 on Cultured Dopaminergic and Gabaergic Neurons of the Ventral Mesencephalon. Journal of Neuroscience. 1994;14(1):335-47.

25. Lingor P, Unsicker K, Krieglstein K. GDNF and NT-4 protect midbrain dopaminergic neurons from toxic damage by iron and nitric oxide. Exp Neurol. 2000;163(1):55-62.

26. Keefe KM, Sheikh IS, Smith GM. Targeting Neurotrophins to Specific Populations of Neurons: NGF, BDNF, and NT-3 and Their Relevance for Treatment of Spinal Cord Injury. Int. J. Mol. Sci. 2017, 18(3), 548.

27. Malin SA, Davis BM. Postnatal Roles of GDNF Family Members in Nociceptors Plasticity. Sheng Li Xue Bao. 2008; 60(5):571-8. 